\title{
Annelies Verdoolaege \\ Dealing with a traumatic past: the victim hearings of the South African Truth and Reconciliation Commission and their reconciliation discourse
}

\begin{abstract}
In the final years of the $20^{\text {th }}$ and the beginning of the $21^{\text {st }}$ century, there has been a worldwide tendency to approach conflict resolution from a restorative rather than from a retributive perspective. The South African Truth and Reconciliation Commission (TRC), with its principle of 'amnesty for truth' was a turning point.

Based on my discursive research of the TRC victim hearings, I would argue that it was on a discursive level in particular that the Truth Commission has exerted/is still exerting a longlasting impact on South African society. In this article, three of these features will be highlighted and illustrated: firstly, the TRC provided a discursive forum for thousands of ordinary citizens. Secondly, by means of testimonies from apartheid victims and perpetrators, the TRC composed an officially recognized archive of the apartheid past. Thirdly, the reconciliation discourse created at the TRC victim hearings formed a template for talking about a traumatic past, and it opened up the debate on reconciliation.

By discussing these three features and their social impact, it will become clear that the way in which the apartheid past was remembered at the victim hearings seemed to have been determined, not so much by political concerns, but mainly by social needs.
\end{abstract}

\section{Keywords}

Post-apartheid South Africa, TRC victim hearings, reconciliation discourse, social impact

\section{Introduction}

Apartheid can be seen as the outstanding traumatic event that has characterised the lives of many South Africans living today. The apartheid regime officially came to an end with the first democratic elections, on the $27^{\text {th }}$ of April 1994, but already quite a few years before this historic date South African society at large had been wondering how to deal with the peaceful coexistence of its population groups. Apartheid had been extremely devastating to the lives of a great many South Africans, so it was clear that atrocities committed under apartheid had to be addressed, in one way or another. 
Attempting to unify South Africa - and even starting the process of reconciling South Africans - became a task assigned to the Truth and Reconciliation Commission (TRC). In this way, the TRC became one of the most significant phenomena in South African history. A lot has been written about the impact the TRC has had on postapartheid South Africa, either on a sociological, legal, political or even literary level. There is no doubt that the impact of the TRC was fundamental and on the basis of my research I would argue that this impact was largely of a discursive nature. It is true that the Truth and Reconciliation Commission basically consisted of discursive practices, such as testifying, complaining, apologising, venting one's rage, expressing one's grief, disappointment or despair. Through the TRC, perpetrators and victims of apartheid started to listen to each other and, to a certain extent, they also tried to understand each other.

In my research, I have focussed on the language constructed at the hearings of the Human Rights Violations Committee (HRVC), the sub-committee of the TRC where the apartheid victims could testify about what had happened to them under apartheid. In contrast with the amnesty hearings, these victim hearings were aimed much more at national unity and reconciliation. The issues of personal and national reconciliation were raised in these testimonies, along with the question of a peaceful and unified future for South Africa. It is the language constructed at these hearings that I have labelled reconciliation discourse.

Through fragments taken from the HRV testimonies I will first give an impression of this reconciliation discourse. On the basis of this exceptional kind of discourse I will then illustrate three discursive features of the Truth Commission three features that made the South African TRC unique, and that resulted in a farreaching influence on South African society. In doing so, we will find out how apartheid was remembered and relived through the testimonies of survivors. At the same time we will understand that this particular construction of reconciliation discourse was strategic - and indispensable - to the social needs of a traumatised post-apartheid South African nation.

\section{The TRC and its Human Rights Violations hearings in a nutshell}

The South African Truth and Reconciliation Commission was called into existence in July 1995. The Preamble of the Promotion of National Unity and Reconciliation Act No 34 of 1995 (the TRC Act) stated that the objectives of the TRC were to promote 
national unity and reconciliation, amongst others by establishing as complete a picture as possible of the gross violations of human rights which were committed under apartheid, by facilitating the granting of amnesty to apartheid perpetrators under certain conditions, and by providing recommendations to prevent future violations of human rights (TRC Report, 1998: 54). In order to achieve these ambitious tasks, three committees were put into place: the Committee on Human Rights Violations (HRVC), the Amnesty Committee and the Committee on Reparation and Rehabilitation. The Committee on Human Rights Violations held public hearings where people could testify about past abuses; the Amnesty Committee considered applications for amnesty; and the Committee on Reparation and Rehabilitation recommended policies to the government regarding reparations for the victims of apartheid.

The HRV Committee - which is the focus of this article - was in charge of collecting written victim statements and of organising the Human Rights Violations hearings, where a representative sample of victims was allowed to testify in public. The HRVC gathered close to 22,000 statements, covering 37,000 violations; this is more than any other previous truth commission had achieved (Graybill 2002: 8). These statements were recorded by trained statement takers who conducted interviews with victims of apartheid all over the country. Between April 1996 and June 1997 a little under 2000 of these victims told their stories before the HRV Committee. Over these 15 months 83 hearings took place in public places such as town halls, schools, churches and civic centres (TRC Report, 1998: 278).

The emphasis of the HRV hearings was on "the validation of the individual subjective experiences of people who had previously been silenced or voiceless" (TRC Report, 1998: 111). Supporters of the TRC claimed that to tell their stories of suffering and misery was a healing and cathartic experience for most of the victims. The mere fact that these survivors were allowed to talk about the past meant a lot to them; it showed that their experiences were officially acknowledged and this made them feel respected as human beings (see Picker, 2003: 20).

Because of the impact it had on the victims and also because the media brought this Committee to the attention of the national and international public, the Human Rights Violations Committee has often been considered as one of the most successful components of the TRC. 


\section{The reconciliation discourse created at the Human Rights Violations hearings}

The Human Rights Violations hearings provided a forum for thousands of apartheid victims to talk about the atrocities they had experienced under the apartheid regime torture, rape, arson, the murder or abduction of beloved ones. When a survivor stepped onto the stage in order to tell his or her story to the HRV Committee, it was stressed, time and again, that he or she was now allowed to talk about the traumatic experience in his or her own words. Victims could testify in the language they preferred and with the help of a team of interpreters they were to tell their stories to an understanding and respectful audience (TRC Report, 1998, 10/1: 282). In practice, the languages used at the hearings were predominantly some of the eleven official languages (du Plessis \& Wiegand, 1997: 13). Taking this into account, though, the interpreters could not cater for the different dialects of the various languages, nor could they always correctly interpret the culturally-specific idioms and speech styles (see also Mpolweni, 2008). As a result, certain groups of victims could not be considered to publicly testify before the HRV Committee.

Based on a thorough reading of all of the Human Rights Violations testimonies, as available on the Official TRC Website (http://www.doj.gov.za/trc/trc_frameset.htm) and a discursive analysis of 30 of them, my research concluded that at these HRV hearings a specific kind of reconciliation discourse was constructed. The central proposition of my research was that the South African Truth and Reconciliation Commission should be regarded as a mechanism to produce power through discourse. Importantly, as will become clear towards the end of this article, the exertion of power should predominantly be regarded as a positive and highly productive aspect. Since I looked at a sociopolitical phenomenon from a discursive perspective, I turned to conceptual frames available in the field of Critical Discourse Analysis (CDA). Some of the aims of CDA are to explore power relations among discourse participants and to reveal how ideologically coloured - power can be expressed through language. By reading through all of the HRV testimonies it became clear that specific discursive patterns could be distinguished. I should stress that the CDA research I consulted solely functioned as background to my theoretical framework. For a detailed analysis of the framework developed, I refer to Verdoolaege, 2008.

In this section of the article I will briefly discuss some characteristics of the discourse taking shape at these hearings; these characteristics indicate that this 
discourse was framed to a certain extent, that it was somewhat guided in a certain direction. The two features that will be highlighted here are the fact that reconciliation was a recurring topic - and even term - at the HRV hearings and the fact that national unity and community spirit were emphasized.

\section{Reconciliation}

First of all, one notices that at the hearings reconciliation itself tended to be strongly emphasised by the TRC commissioners. They sometimes urged the victims to speak out in favour of reconciliation - in particular having the testifiers pronounce terms such as 'reconciliation' or 'forgiveness' appeared to be of the utmost concern. In some instances, victims were explicitly asked whether they would be prepared to meet their perpetrators, whether they would be prepared to talk to the perpetrator, or, very straightforwardly, whether they would be willing to actually reconcile with the wrongdoer. This is an example of this discursive method, whereby commissioners explicitly asked the testifier to reconcile ${ }^{1}$. It comes from Mrs. Gladys Papu, whose husband was killed by a rival political group. After she has told her story and answered the additional questions, commissioner Xundu concludes the testimony. He raises the question of reconciliation in this way:

REV XUNDU: Thank you Mr Chairperson. Mam, I heard your story. I only have one question. According to you what can be done so that there can be peace? Is there a conflict between yourself and this other group?

MRS PAPU: What I want is for them to come forward to tell the truth.

REV XUNDU: You are saying that reconciliation can be built if they can come forward?

MRS PAPU: Yes, if they can come and tell the truth.

REV XUNDU: If they can come forward you will forgive them? MRS PAPU: Yes.

REV XUNDU: Thank you.

In this example it seems as if commissioner Xundu literally puts the words of forgiveness and reconciliation in the mouth of the testifier. It then became almost impossible for the victim to react against this reconciling atmosphere or to even try to

\footnotetext{
${ }^{1}$ All of the fragments cited in this text are literally taken from the Official TRC website. Spelling mistakes and grammatical errors have not been corrected. The italics in the cited fragments are always my own.
} 
modify the language of the commissioners. Commissioner Xundu keeps repeating the terms reconciliation and forgiveness, until the testifier admits that she fully agrees with what he says. The commissioner is posing leading questions and it seems to be a question of actually pronouncing these terms out loud - in this way the attention of the TRC audience would be focussed on the importance of establishing interpersonal reconciliation.

A second example has to do with the written statements the victims' testimonies were based on. Indeed, all of the testifiers had submitted a written statement before appearing before the Commission. Sometimes, the commissioners read parts from these statements, to remind the testifier of what he or she had stated before. In some cases, the commissioners emphasised that reconciliation had been expressed in the written statement and they explicitly read the appropriate fragment to the victim. In this way, people had to confirm that they had been in favour of forgiveness and reconciliation, at least at the time when they gave their statements. It was then very difficult for the testifier to retract these words by proclaiming vengeance or hatred instead.

An example of such explicit reference to a written statement comes from the testimony of Mrs. Manzala Dingumhlaba. She spoke about the torture of her father. The concept of reconciliation is introduced by commissioner Crichton:

MS CRICHTON: I want to ask you a question, because in your statement you said something that has interested me deeply and I want not only the Commission to hear this, I want the people that are listening to this across South Africa to hear it as well, because there is a need for them to hear it. May I quote from what you said in your statement about the perpetrators? In your statement you said:

"I wish that the perpetrators would ask for forgiveness and compensate me for the loss of my father and the humiliation that they caused."

Do you remember saying that?

MS DINGUMHLABA: Yes I remember.

MS CRICHTON: Is that still your wish?

MS DINGUMHLABA: Yes, I want them to ask for forgiveness, because we are left as orphans. 
MS CRICHTON: Thank you very much. Thank you Mr Chairman.

Finally, committee members frequently concluded testimonies by using reconciliationoriented phrases. Testifiers were praised if they had displayed reconciling attitudes in the course of their testimonies or if they were prepared to forgive their perpetrators. If victims had been resentful, committee members sometimes attempted to temper these feelings. They kept emphasising that reconciliation was the only way to build a new South African society. If testimonies were concluded by creating such a reconciliation-oriented atmosphere, it could become extremely hard for the next testifier to talk in a spirit of vengeance or retaliation. This is an illustration from the testimony of Kenneth Manana, a former member of the liberation movement who was arrested and tortured by the South African Police. He openly expressed feelings of forgiveness in the course of his testimony and this is picked up by commissioner Mkhize in her final statement:

MS MKHIZE: We would like to thank you for having been able to come. We also thank you for having started a new life. Also being ready to reconcile and forgive. As you have already said that you are a new man, you have repented. We pity you for having suffered under the hands of the police. We also believe that you work with us to add any information that we might need in your statement. Thank you very much.

I would suggest that a reconciliation-oriented atmosphere was deliberately created at the HRV hearings. On a personal level, individual testifiers probably covered a wide range of attitudes, veering between supporting and rejecting the concept of reconciliation. Through interaction with the commissioners, though, these personal attitudes were homogenised. When watching or listening to these testimonies it may look as if the majority of the victims embrace reconciliation. A closer analysis tells us that the TRC commissioners were often the driving force behind this commitment to reconciliation, but that testifiers could also challenge or transform this proposed frame. I see this commitment to reconciliation as one of the crucial aspects of the reconciliation discourse that was constructed during the victim testimonies. 


\section{National unity}

According to the TRC Act, the objectives of the Commission were not only "to promote reconciliation", but also to "promote national unity in a spirit of understanding which transcends the conflicts and divisions of the past..." (TRC Act, chapter 2, 3 (1)). In the same way as with reconciliation, the TRC also had to try to contribute to the process of nation building; it was not supposed to establish national unity right away. Also in this case, the role of the TRC was dual. On a concrete level, the drive for nation building was directed towards the testifiers. Both the amnesty applicants and the victims had to feel accepted and respected in the new South Africa. Ideally, they should feel a desire to reach out to fellow South Africans, perpetrators as well as victims, in order to establish a united future. On the other hand, with regard to national unity, the TRC also had a symbolic function, aimed at the South African public at large. In essence, people had to be shown explicitly that there was a desire to build a nation among South Africans, meaning that the testifiers were urged to express their commitment towards a unified country. In addition to establishing a national identity among apartheid victims, the commissioners also tried to enhance community spirit among the HRV testifiers. What I have labelled community spirit can be seen as an aspect of national unity and national solidarity. Community spirit, as I understand it here, refers to showing consideration for other community members and wanting to live together peacefully at the level of the local community.

Throughout the hearings this aspect of community spirit was frequently stressed. Caring about other members of one's community could indicate a willingness to build a society together - an awareness of communal solidarity. Let me give a few examples of this typical feature of the HRV discourse.

The ideological value of nation building was especially enhanced by emphasising the need for national unity and through proclaiming equality of all victims in the closing statements of the testimonies. The closing statement of Mrs. Nkabinde's testimony, for instance, was clearly oriented towards national unity. Nkabinde was a supporter of the Inkatha Freedom Party (IFP) and she was attacked by members of the ANC. Mrs. Nkabinde was one of the rare IFP victims who came forward to the TRC - the IFP officially boycotted the Commission. Therefore, her testimony is used by the commissioner to stress that victims from different sides of the apartheid conflict suffered equally: 
COMMISSIONER LAX: You must have heard the evidence of the lady before you, Mrs Khumalo. She told a similar story to you about being attacked in her own house, the house being set alight, and in her case she said it was members of the IFP who did that. In your case you said it was members of the ANC. And our view is that from wherever this violence comes it's wrong, and that you and Mrs Khumalo are sitting here together, you are members of different parties, but you have both been victims of violence. And what has that violence brought to you? Nothing except sadness, fear, misery. And we hope that the message will go out from this Commission that violence doesn't help anything.

Just as with the feature of introducing reconciliation, the idea of community spirit was sometimes hinted at by the commissioners by referring to the written statement of the testifier. One example comes from Wandile Mbathu, who was injured at the Bisho massacre. At the end of his testimony commissioner Sandi inquires about Mr. Mbathu's requests before the Commission:

ADV SANDI: Do you have a request to put forward to the Commission? MR MBATHU: I request that as I am injured, that I could get my money because it's quite problematic. I need pension.

ADV SANDI: I notice here that there is another request that you have made, that has nothing to do with you personally. Do you remember that request?

MR MBATHU: Yes I do.

ADV SANDI: Can you tell us Mr Mbathu?

MR MBATHU: I said I wanted a house.

ADV SANDI: Did you not say that this Commission should ascertain or make a request to the government to build houses for victims like you?

MR MBATHU: Yes I did say.

ADV SANDI: Do you have another request that you would like to make Mr Mbathu? MR MBATHU: No I do not but I just need my money because I was injured.

It looks as if commissioner Sandi urges the testifier to admit what was expressed in the written statement - the request to the government to build houses for apartheid victims. Requesting houses for fellow-victims was a typical example of community awareness. It indicated that the victim was concerned about the well-being of the community as a whole, and not solely about his or her own problems. The first request spontaneously expressed by this testifier talks about a pension: Mr. Mbathu 
has been injured, so he wants financial compensation. Adv. Sandi then refers to the written statement, hinting at another request "that has nothing to do with you personally". Apparently, he wants to hear the communal request from the mouth of the testifier himself.

In cases like these an atmosphere of national solidarity and communal awareness was established. One of the messages thus spread to the TRC audience might be that, since the victims seemed to be committed towards community spirit and national unity, also the nation at large should put in an effort to strive for nationwide togetherness. In such a context of community awareness, testifiers were more willing to commit themselves to communal values - in this way, it was more likely that they felt part of the nation building-story of the new South Africa, a feature I will focus on later in this article.

I have only discussed two - though very essential - characteristics of the reconciliation discourse created at the Human Rights Violations hearings. A few more characteristics of this discourse can be distinguished, such as the fact that emotional discourse - descriptions of torture experiences and elaborations on physical or medical conditions - tended to be valued, the fact that the commissioners took an objective stance vis à vis the South African political parties, and the fact that attributing respect to the victims was of utmost importance.

I cannot elaborate on these features here, but what I have tried to illustrate is that at the HRV hearings the testifiers' linguistic space was somewhat confined - for instance through the fact that the leading commissioners kept raising specific topics, such as reconciliation and national solidarity. In fact, this discourse took shape mainly on the basis of the stimulating input of the HRV committee members. It was these commissioners who guided the testimony and who dominated the interaction with the testifiers. However, what I did not illustrate here (for details, see Verdoolaege, 2008) is that the testifiers often added extra layers to this master narrative - for instance by interpreting reconciliation in a very personal manner, or by only conditionally accepting the concept of communal solidarity. This means that also the individual testifiers provided significant input, by accepting or rejecting the framing of the commissioners and by constantly negotiating acceptable indexicalities. We can conclude by stating that although the voice of the commissioners was dominant, the HRV testimonies were definitely co-constructed. The reconciliation discourse was created at the HRV hearings through an interactional process - by commissioners 
introducing certain topics and by testifiers either accepting, modifying or ignoring these topics.

In the following section I will discuss three features through which this reconciliation discourse seems to have had a positive impact on South African society

\section{The link with South African society}

The concrete discursive practices taking place at the HRV hearings comprise what Foucault has termed a discursive regime (see Kellsall 2004: 7). Such a discursive regime is always linked to a regime of truth - or, put differently, discourse always contributes to the creation of new truths (Gqola 2001: 4). At the HRV hearings a specific discursive regime was constructed. Through this selective procedure, this strictly regulated and controlled discourse contributed to the creation of new realities, new truths. This means that the TRC not only focussed on retrieving the truth about the past (see TRC Report 1998, 1/5: 109-113), it also had the authority to capture, to establish and to codify the truth. This dimension of truth recovery was not so much oriented to the past; it was rather directed towards the present and the future. In this section I will specifically focus on three manners in which the above-described reconciliation discourse had a long-lasting impact on South African reality - ways in which this discourse contributed to the establishment of new truths and new visions of citizenship and society.

\section{Giving a voice to 'ordinary citizens ${ }^{2}$,}

Firstly, the TRC provided a discursive forum for thousands of 'ordinary citizens', thus giving them the opportunity to participate in the story of nation building. A little under 2000 apartheid victims came to the HRV Committee to talk about their suffering under apartheid. These victims came from South African towns, villages or remote areas and the majority of them did not have a high political, social or religious profile (personal conversation with Nicky Rousseau, co-author of the TRC Final Report). These victims can be considered as ordinary South Africans, testifying in their own mother tongue and surrounded by family and friends to support them. Some

\footnotetext{
${ }^{2}$ I put 'ordinary people' or 'ordinary citizens' between inverted commas, since none of these testifiers were 'ordinary' in the strict sense of the word. Tutu $(1999: 82,120)$ even calls them 'VSP, Very Special People'. 'Ordinary' merely refers to the fact that they usually did not hold official (social, political, cultural) positions.
} 
scholars, however, such as Mamdani (2000: 61), have claimed that the TRC only concentrated on the very narrow distinction between one particular kind of 'perpetrator' and one particular kind of 'victim'. Mamdani argued that the vast majority of victims who appeared before the Commission were political activists - so not 'ordinary people' (see also Brent Harris, 1998: 26) - and that the majority of perpetrators were apartheid officials. As a result, as claimed by these critics, the Commission only revealed a partial truth and definitely not 'the truth' about the apartheid past (Cherry, 2000; Pigou 2003).

I would argue, though, that many apartheid victims had not been activists; they had experienced apartheid as an evil system or they had been indirect victims. The latter was often the case with women whose husbands were active in the struggle against apartheid. If their husbands got arrested or killed it often became extremely difficult for these women to earn a living and to morally support their families. These women did not suffer from 'gross human rights violations', but still they had been victims of apartheid. One of the great merits of the TRC is that it gave a voice to these 'ordinary citizens'. We could argue that by testifying before the TRC these people participated in the story of nation building. This was especially the case because at the HRV hearings, as we have seen in the previous section, an atmosphere of national unity and reconciliation tended to be created. Testifiers became convinced that working and living together in the new South African was a necessity and that by giving their testimony before the TRC they participated in the writing of a new beginning to South African history. This was a way to increase their commitment to the new South African nation and to enhance their willingness to work together in the construction of a peaceful future. Victims were highly respected before the TRC and they were free to express their - political - ideas and opinions, which added to the inclusive nature of the TRC. As a result, the testifiers really seemed to belong to the historical TRC process.

Put differently, the impact exerted by the TRC on a socio-political level can be conceived as positive since it was a mechanism to decentralise power. All people who had participated in the TRC process - victims, perpetrators, TRC staff, but also the media, politicians, researchers and artists who used TRC material - felt as if they had contributed to 'the building of a unified and reconciled nation'. All of these people felt powerful to a certain extent and they felt proud to be part of the new nation. Because the testifiers were given a voice before the TRC they understood that they 
were now esteemed citizens of the new South Africa; they had gone from subjected people to subjects of the new state. They realised that their country was setting an example to the world and they felt part of this unique undertaking.

Giving a voice to these ordinary and previously powerless citizens can be seen as one of the most important characteristics of the South African TRC.

Testifying gave these survivors the impression to really belong to both the transitional processes and the new nation, which was beneficial for the entire project of nation building.

\section{The constitution of an official archive}

Secondly, by means of the testimonies of apartheid victims and perpetrators, the TRC composed a collective memory, an official archive of the apartheid past. This archive is reflected in the TRC Report and, even more importantly, in the recordings and the transcriptions of the testimonies. The establishment of the Truth and Reconciliation Commission, its proceedings and its final results, were an attempt to reconstitute South Africa's apartheid past. The apartheid experience was to be reconstructed and then recorded and treasured to serve as a reminder of the past for future generations. Thousands of testimonies were gathered, many of them were distributed in public, a Final Report summarised the Commission's findings, an official website made the entire TRC process accessible to the international community, and many books, articles and dissertations reflected on the proceedings and the outcome of the Commission. In this way, the TRC can be considered as a place of archive; more particularly, it is a public archive (Derrida 2002: 49). The archive is a dual concept, which refers not only to the past, by means of repetition and remembrance, but also to the future. Derrida (1996: 68) therefore calls the archive "the affirmation of the future to come". An archive is an extremely powerful institution; based on what is included or excluded from the archive, it is decided what will be remembered and forgotten in the future. An archive constitutes the collective memory of a society; a collection that will always be there to consult and that, as a result, can gradually be forgotten by the people of that society. Indeed, the archived records are being stored away in order to be able to forget them - because you know that it will be possible to retrieve them again when needed. This officially authorised and undeniable archive will for ever be cherished by future generations. There does exist a record of the apartheid past now and this record will always be there to be reflected upon and 
analysed. Therefore, not only the act of testifying was a way to psychologically deal with the apartheid past; also the knowledge that these testimonies were recorded and stored away indicated that a chapter in history could be closed off. Creating an officially recognised archive that is open to the public and to national and international researchers is also a - discursive - aspect of the TRC that had a positive impact on the way apartheid survivors conceptualised the new South African future.

\section{Creating a testimonial template}

Thirdly, the Human Rights Violations hearings formed a template for talking about a traumatic past. Although the South African Truth Commission was the sixteenth commission of its kind, starting with the Ugandan Commission of Inquiry in 1974 (Hayner 2001: 291), at the time of being established it did have a number of particular characteristics. One such unique aspect was the transparency and the public nature of the TRC. The truth commission in Argentina, for instance, did not hold public hearings, and also the public character of the Chilean commission (media attention, public testimonies of victims) was more limited (Hayner 2001: 33-36). The South African TRC really formed a turning point, nationally as well as internationally. On a national level, it had always been difficult for South Africans to talk about apartheid atrocities, to express emotions of grief and anger - definitely not in public, and definitely not when the stories involved themselves or beloved ones. As a result of the TRC testimonial format people were now provided with an institutional template to listen to victims, to pay respect and to deal with their emotions and memories. Indeed, despite the apparent ambiguity and complexity present in the discourse used at the HRV hearings, many observers have noted how the victim hearings became 'standardised' and 'ritualised' very soon after the first ones were held in East London in April 1996 (Graybil 2002: 82, Ross 2003). Wilson (2001: 111-112) pursues a similar analysis in his description of the 'interpretative template' laid across individual victims' testimonies. He identifies four predictable chronological stages - recognising and collectivising suffering, the moral equalising of suffering, liberation and sacrifice, and redemption through forsaking revenge - that describe the routine ways commissioners took the stories of victims.

It was not only the format of the testimonies that was soon 'routinised'; a similar process of standardisation took place at the level of the stories' content. In fact, the stories at these hearings were primarily event-centred and individual 
accounts of physical suffering. Structural or everyday violations experienced by individuals, families and communities were not so much addressed (Colvin 2003: 3). Very soon, according to Colvin, one could notice the emergence of an ideal-typical testimonial process in the course of the HRV hearings.

This kind of storytelling as promoted by the TRC has then become the predominant model for speaking about suffering in the past in South Africa. The fact is that there were few precedents for this kind of public testimony about the apartheid past. And, especially, not a lot of other storytelling genres existed with the same kind of public recognition and legitimacy as enjoyed by the TRC testimonies. Still today a number of victim-oriented organisations in South Africa make use of the storytelling format as it was developed during the HRV hearings. Let me give the example of the Khulumani Support Group (KSG). As a non-governmental organisation KSG was established in 1995 by the survivors and families of the victims of South Africa's apartheid regime. Khulumani means "Speak Out" in Zulu and was formed as an umbrella body operating under the Centre for the Study of Violence and Reconciliation (CSVR), until it de-linked itself in 1999. In its initial phase, KSG helped South Africans to gain access to the TRC process and it dedicated most of its time and resources to addressing the demands of the Truth and Reconciliation Commission. From 2000 onwards it helped victims to voice their opinions and make known their needs, amongst others by organising discussion groups where people can talk about their experiences under apartheid. ${ }^{3}$

Additionally, after the closing down of the TRC, voices were raised that the process should be repeated on a smaller scale. It was claimed that schools, churches, companies and private institutions, for instance, should establish their own internal truth commissions to investigate atrocities committed under apartheid. These internal mini-TRC's would provide a space for people and organisations to confront the past and they would also produce sets of recommendations. The Faculty of Health Sciences at Wits University, for instance, has launched an internal reconciliation commission process and it is claimed that such an initiative could be an effective mechanism for achieving change at the local level (Goodman \& Price 1999: 18). Both these internal commissions and the discussion groups at Khulumani are

\footnotetext{
${ }^{3}$ See http://www.khulumani.net/
} 
examples of forums where the story-format as standardised at the HRV hearings was brought into practice.

Importantly, the HRV hearings not only had a direct impact on the establishment of other discussion forums to deal with the apartheid past, they also opened up the debate on reconciliation in South Africa. After the transition to democracy in 1994 a new discourse had to be established to talk about South African society. As claimed by Gobodo-Madikizela (2003: 56 ), it is always necessary to forge a vocabulary of peace in the aftermath of mass tragedy. People had to start thinking about one another differently, which also involved talking about and to one another by means of a language adapted to the new dispensation. According to my interpretation, it is in this search for a new socio-political discourse that the TRC acted as a catalyst, with the HRV reconciliation discourse forming the foundation of this wider societal discourse.

For more than two entire years - from April 1996 till July 1998 - South African society was permeated by the proceedings of the HRV Committee. The national as well as the international media devoted a lot of attention to the hearings of the HRVC (Wilson 2001: 21). It was especially the individual public hearings, along with extensive media coverage, that caused the notion of reconciliation to filter through to South African society (Goodman 2003: 80). People started to reflect on reconciliation and to look at the feasibility of reconciliation in their personal lives. Also internationally, reconciliation became the identifying label of South Africa - only look at the fact that South Africa is regularly framed as a 'rainbow country' or a 'multicultural' nation, characterised by 'diversity' and peaceful coexistence (Rassool 2000: 1).

Based on my research I would argue that the TRC probably contributed to the continuation of an atmosphere of reconciliation among South Africans after 1994. This is also put forward by Gibson (2004) after having carried out his research on current day attitudes towards reconciliation in South Africa. He maintained that "[those South Africans] who are more accepting of the TRC's version of the truth are more likely to be reconciled" and "accepting the TRC's truth certainly did not contribute to 'irreconciliation'” (Gibson 2004: 334-335). To me, the impact of the TRC might not have been manifest; it is not a tangible result we can clearly pinpoint. Instead, it can be described as an underlying current, a tendency to reconciliation many South Africans might not be openly aware of. This corresponds to the ideas 
expressed by Antjie Krog in the epilogue to the 1999-edition of her book 'Country of My Skull'. In this postscript she wonders whether the TRC process has indeed achieved reconciliation in South Africa. What is not visible, she claims, is "reconciliation as a mysterious Judaeo-Christian process". Instead, what we see daily is "reconciliation as one of the most basic skills applied in order to survive conflict". Therefore, Krog also seems to be convinced that it is first and foremost in the daily lives of South Africans that we find this intangible spirit of reconciliation. The Institute for Justice and Reconciliation as well states that "The notion of reconciliation has firmly rooted itself in the parlance of South African society"

(http://www.ijr.org.za/politicalanalysis/reconcbar). Indeed, I would claim that it is partly as a result of the HRV reconciliation discourse that reconciliation became a point of discussion in South Africa. The concept became part of South African public life, which might have influenced people's perspective on society.

It is important to note, though, that this positive impact of the TRC was especially notable in the years immediately following the Commission's proceedings. The South African Reconciliation Barometer indicated that in 2008 there was a manifest decrease in optimism relating to the peaceful coexistence of people of different races. This is particularly worrying since contact and social interaction between the country's four main constitutive groups have increased. This shows, according to the Reconciliation Barometer, that "even 15 years after the end of apartheid, we can not afford to let the quest for national reconciliation be watered down to simply amount to 'forgiving and forgetting" (http://www.ijr.org.za/politicalanalysis/reconcbar). Reconciliation still needs to be worked on and this on a daily basis. Small scale initiatives have been initiated and many individuals have continued their journey of personal reconciliation in the aftermath of the TRC (see du Toit, 2003). It is crucial to continue this kind of 'reconciliation building', for instance by taking the HRV hearings and its reconciliation discourse as a source of inspiration.

\section{Conclusion}

In the section on reconciliation discourse I claimed that the freedom of expression of testifying victims was regimented to a certain extent at the HRV Committee. Therefore, it might seem as if I merely regarded the entire HRV discourse as being solely constructed on the basis of underlying ideological motivations - hence not 
really serving the interests of the apartheid victims. A number of authors have been quite critical about the freedom of expression granted to HRV testifiers (Bock et al 2000; Grunebaum-Ralph 2001: 201) and indeed, I would say that discursive constructionism was definitely an issue at the victim hearings. Additionally, some critics (see Jefferey 2001: 85; Kjeldgard \& Nexo 1999: 45) have considered the TRC as a political instrument. See also the publication by Claire Moon (2008), who claims that at the TRC reconciliation was animated to legitimize the incoming regime. It seems to be clear that the TRC did have a political agenda indeed: its objective was to start a process of national reconciliation, whereby inclusive nation building was definitely a political exercise. The reconciliation discourse created at the HRV hearings, with its strong focus on reconciliation and nation building, could thus be seen as part of this political agenda. In this way we could argue that the discursive constructionism has been strategic to current political concerns.

However, in the second half of the article I have tried to elaborate on the positive effects of the HRV reconciliation discourse, which indicates that constraining discourse should not necessarily be conceived negatively in the case of the TRC. It has to be clear that I see the TRC first and foremost as a positive initiative. Not only was the Commission the only possible and indispensable option in post-apartheid South Africa - there was simply no alternative, except for a civil war-scenario; I also hope to have shown that especially on a discursive level the TRC has had a positive impact on South African society. It is therefore reasonable to state that the constructed reconciliation discourse has not only been important on a political level in South Africa, but that it was South African society in particular that - in an attempt to deal with the apartheid past - needed such a kind of discourse: a discourse that included and empowered a large number of South Africans, a discourse that was archived and remembered forever and a discourse that could be taken as an example when reflecting on the traumatic past. In short, a discourse that laid the foundation for a society-wide atmosphere of reconciliation.

To conclude I would argue that it is quite understandable that conflict-resolving mechanisms in other countries have openly taken the South African TRC as a model (for examples see the site of the International Centre for Transitional Justice at http://www.ictj.org). This means that the influence of the TRC reaches far beyond its local context. Not only did the Commission facilitate a national discussion on gross human rights violations and on issues of justice, reconciliation and democracy. It is 
also quite likely that the TRC instigated the worldwide debate on the value of restorative versus retributive conflict resolution.

\section{References}

Bock, M., McCormick, K. and Raffray, C. 2000. "Fractured truths: Multiple discourses in South Africa's Truth and Reconciliation Commission." Paper presented at Centre for African Studies Seminar, University of Cape Town, August 2000.

Cherry, J. 2000. "Historical truth: something to fight for." In Looking Back, Reaching Forward, Reflections on the Truth and Reconciliation Commission of South Africa, Ch. Villa-Vicencio and W. Verwoerd (eds.), 134-143. Cape Town: University of Cape Town Press.

Colvin, C.J. 2003. "Limiting Memory: the Roots of Storytelling in Post-Apartheid, Post-TRC South Africa." In Telling Wounds. Narrative, Trauma \& Memory. Working through the SA armed conflicts of the $20^{\text {th }}$ century. Proceedings of the conference, C. van der Merwe and R. Wolfswinkel (eds.), 234-244. Stellenbosch: Van Schaik Content Solutions

Derrida, J. 1996. Archive fever. A Freudian impression. Chicago: The University of Chicago Press

2002. "Archive Fever in South Africa." In Refiguring the Archive, C. Hamilton et al (eds.), 3880. Cape Town: David Philip Publishers.

Gibson, J.L. 2004. Overcoming Apartheid. Can Truth Reconcile a Divided Nation? New York: Russell Sage Foundation.

Gobodo-Madikizela, P. 2003. "Alternatives to Revenge: Building a Vocabulary of Reconciliation Through Political Pardon." In The Provocations of Amnesty: Memory, Justice and Impunity, Ch. Villa-Vicencio and E. Doxtader (eds.), 51-60. Claremont: David Philip Publishers.

Goodman, T. and Price, M. 1999. "Continuing the TRC Project: The Use of Internal Reconciliation Commissions to Facilitate Organisational Transformation - the Case of the Wits Health Sciences Faculty." The TRC: Commissioning the Past Conference. Johannesburg: University of the Witwatersrand, 11-14 June 1999.

Gqola, P.D. 2001. "Defining people: Analysing power, language and representation in metaphors of the New South Africa." Transformation 47: 94-106.

Graybill, L.S. 2002. Truth and Reconciliation in South Africa. Miracle or Model? Boulder: Lynne Rienner Publishers, Inc.

Grunebaum-Ralph, H. 2001. "Re-Placing Pasts, Forgetting Presents: Narrative, Place, and Memory in the Time of the Truth and Reconciliation Commission." Research in African Literatures 32 (3): 198-212. 
Harris, B. 1998. "'Unearthing' the 'Essential' Past: The TRC and the Making of a National Public Memory." South African and Contemporary History Seminar. $28^{\text {th }}$ April, 1998, University of the Western Cape, Bellville.

Hayner, P.B. 2001. Unspeakable Truths. Confronting State Terror and Atrocity. London: Routledge.

Institute for Justice and Reconciliation. Reconciliation Barometer. 2009.

http://www.ijr.org.za/politicalanalysis/reconcbar.

International Center for Transitional Justice Website. 2009. http://www.ictj.org/.

Jefferey, A. 2001. The Truth about the Truth Commission. Johannesburg: South African Institute for Race Relations.

Kelsall, T. 2004. Politics, anti-politics, international justice: notes on the special court for Sierra Leone. Settling Accounts: Truth, Justice and Redress in Post-Conflict Societies Conference. Weatherhead Centre for International Affairs: Harvard University, 1-4 November 2004

Khulumani Support Group Website. 2009. http://www.khulumani.net/home.html. Kjeldgard, P. and Nexo, E.A. 1999. The South African Truth and Reconciliation Commission - a Tragedy of True Lies and Video-tapes. Roskilde University, Denmark.

Krog, A. 1998. Country of My Skull: Guilt, Sorrow, and the Limits of Forgiveness in the New South Africa. Parklands: Random House South Africa.

Mamdani, M. 2000. "A Diminished Truth." In After the TRC, Reflections on truth and reconciliation in South Africa, W. James and L. Van de Vijver (eds.), 60-63. Cape Town:

David Philips Publishers.

Moon, C. 2008. Narrating Political Reconciliation. South Africa's Truth and Reconciliation Commission. Lanham: Lexington Books.

Mpolweni, N.L. 2008. "The Importance of the Original: Challenges in Interpreting a Xhosa Testimony Before the South African TRC." Journal of Multicultural Discourses 3(3): 221-232. Official TRC Website. 2009. http://www.doj.gov.za/trc/trc frameset.htm.

Picker, R. 2003. "Victims' Perspectives about the Human Rights Violations Hearings." Paper Online: http://www.csvr.org.za/wits/papers/pappick.htm.

Pigou, P. 2003. "Degrees of Truth: Amnesty and Limitations of the Truth Recovery Project." In The Provocations of Amnesty: Memory, Justice and Impunity, Ch. Villa-Vicencio and E. Doxtader (eds.), 217-236. Claremont: David Philip Publishers.

Plessis du, Th. and Wiegand, C. 1997. "Report on interpreting at the hearings of the Truth and Reconciliation Commission: April 1996 to February 1997." Acta Varia. Onderweg na vertaal- en tolkopleiding in Suid-Afrika 3: 10-29.

Rassool, C. 2000. "The Rise of Heritage and the Reconstitution of History in South Africa" Kronos: Journal for Cape History 26: 1-21. 
Ross, F.C. 2003. Bearing Witness: Women and the Truth and Reconciliation Commission in South Africa. London: Pluto Press.

Toit du, F. 2003. Learning to live together. Practices of social reconciliation. Cape Town: Institute of Justice and Reconciliation.

TRC Act Online. 1995. http://www.doj.gov.za/trc/trc frameset.htm. Truth and Reconciliation Commission of South Africa Report. 1998. Volumes 1-5. Cape Town: Juta \& Co Ltd.

Tutu, D. 1999. No Future without Forgiveness: A personal overview of South Africa's Truth and Reconciliation Commission. London: Rider Books.

Verdoolaege, A. 2008. Reconciliation Discourse. The case of the Truth and Reconciliation Commission. Amsterdam: John Benjamins Publishing Company

Wilson, R.A. 2001. The politics of Truth and Reconciliation in South Africa. Legitimising the Post-Apartheid State. Cambridge: Cambridge University Press. 